\title{
Wind Shear Effects on Water Accumulation and Rain Duration in Hawaiian Warm Clouds
}

\author{
By Tsutomu Takahashi \\ Cloud Physics Observatory, Department of Meteorology, University of Hawaii, Hilo, Hawaii 96720 \\ (Manuscript received 16 January 1986, in revised form 7 May 1986)
}

\begin{abstract}
Aircraft observations of warm rain in Hawaii were analysed concerning the effect of wind shear on the drop growth processes in different cloud types. Drizzle formation is slowed near the cloud top when a strong wind shear exists in an isolated cumulus clouds or a band clouds, while drizzle formation is accelerated with presence of a strong wind shear in cloud clusters. A moderate updraft is needed for raindrops to grow near the cloud top. As drops fall through a cloud, rainwater is accumulated best in cloud clusters and least in isolated cumulus clouds. Rain duration becomes shorter with a strong wind shear in isolated cumulus clouds, but rain lasts for a long period of time from band clouds where the wind is parabolic in form and a strong wind blows at the middle of the trade wind layer.
\end{abstract}

\section{Introduction}

The simple but efficient rainfall process that occurs in oceanic tropical warm clouds attracts many workers. The most substantial work in recent warm rain study may be the revision of the old giant nuclei theory (Woodcock et al., 1972, Takahashi, 1976).

In Australia, Warner (1969) made an extensive study on the cloud drop growth processes of non-precipitable warm clouds. On the other hand, in Hawaii Takahashi (1977, 1981a; hereafter called Paper A and B) investigated the drop growth processes of precipitable clouds with the use of aircraft. Takahashi (1981a, 1982) showed that raindrops have already started to develop near the cloud top. The drop growth mode, however, varies greatly with cloud type. The first purpose of this paper is to study the effect of wind shear as a major influential parameter affecting drop growth rates.

Another interesting topic is the study of differences in rain duration. Rain duration becomes shorter with a strong wind shear. However, band clouds which form in a special wind shear condition produce longer-lasting rain than do isolated cumulus clouds (Takahashi, 1982).
This paper will address the further study of rain duration with respect to wind profile.

\section{Aircraft data}

Aircraft observations focused on morning showers during the observational period of March to July in the years 1976-1979. More than 300 flight hours were logged and 163 different clouds were studied.

Most observations were carried out near the coast on the upwind side of Hilo, Hawaii, from 0500 to 0800 hours. Although 7 a.m. pibal data is available, rainfall frequently occurs at that time which interferes with the wind sounding data set. Since the 7 a.m. pibal data was closer in character to the $0100 \mathrm{LST}$ radiosonde soundings during typical trade wind conditions, especially in the upper part of the trade wind layer where most wind analysis were made, the regular midnight soundings from the National Weather Service Station at Hilo were used for wind and temperature information. However, on days when the 1300 LST sounding did show a significantly different wind profile from the 0100 LST sounding, the aircraft data that was taken that day was rejected for analysis. 
Aircraft data includes cloud droplet size distribution near the cloud base, cloud droplet, drizzle and raindrop size distributions near the cloud top ( $200 \mathrm{~m}-300 \mathrm{~m}$ below cloud top) during the entire cell life (Paper B), and timespace rainwater content (cases when maximum rainfall intensities are roughly higher than 0.5 $\mathrm{mm} \mathrm{h}^{-1}$ ) with raindrop size distribution beneath the cloud base during the entire shower life (Paper A). The aircraft is also equipped with a Johnson-William cloud drop water content meter, a reverse-flow type thermometer and Lyman- $\alpha$ humidiometer. More detailed equipment information can be found in previous papers (Papers A, B). The instrument used to measure air motion is primitive. Level-flight use of a variometer may result in an underestimation of vertical motion and may create a time lag in comparison to the actual motion. Here it is used to indicate relative values of vertical velocities. Aircraft traverses are always done in alternating directions to ascertain that the drop distributions in the updraft profiles have similar tendencies regardless of the direction of flight. Flights are mostly conducted along the prevailing wind direction and flight speed is $45 \mathrm{~ms}^{-1}$ in the cloud and $30 \mathrm{~ms}^{-1}$ beneath the cloud base.

Complete sets of data during entire cell life were not always available. Since drop growth proceeds successively with time and space, proper flight paths enabled to keep track of drop growth processes.

\section{Classification of clouds}

Clouds are generally classified into two groups; isolated cumulus clouds and band clouds. A third group is created for cloud clusters those showing many distinct updrafts near the cloud top. Of the series of clouds studied 74 cases are classified as isolated cumuli, 74 cases as band clouds and 15 cases as cloud clusters.

\section{a. Isolated cumulus clouds}

When the wind is relatively weak or a northerly wind blows, isolated cumuli commonly develop over the ocean upwind of Hilo (Paper B). The temperature lapse rate is normally $6^{\circ} \mathrm{C}$ $\mathrm{km}^{-1}$ within the trade wind layer and a relatively strong inversion, about $1^{\circ}-2^{\circ} \mathrm{C}$ within $200 \mathrm{~m}$, is commonly observed. Humidity drops from $80-90 \%$ to $10 \%$ within $2-300 \mathrm{~m}$ at the inversion level. The inversion height varies from 2 to $3 \mathrm{~km}$. The cloud base height is about $500 \mathrm{~m}$ and the cloud top height is slightly above the inversion height. During rainfall, the cloud base height increases and only an upper-level stratified cloud remains after the rain. In rare cases the trade wind layer is extremely moist and the temperature lapse rate is small, $5^{\circ} \mathrm{C} \mathrm{km}^{-1}$. In this case, the cloud is less turbulent and disappears with drizzle fall. The maximum cloud top water content near the cloud top (about $200 \mathrm{~m}$ below cloud top) depends upon the cloud diameter. Maximum average values range from $0.7 \mathrm{gm}^{-3}$ for $1 \mathrm{~km}$ of cloud diameter to $2 \mathrm{gm}^{-3}$ for $4 \mathrm{~km}$ of cloud diameter. The diameters of cloud we observed were typically $2-4 \mathrm{~km}$.

\section{b. Band cloud}

When the vertical wind profile is parabolic, band clouds often develop early in the morning over the ocean in perpendicular to the wind direction and in parallel to the coastal line, about $15 \mathrm{~km}$ upshore from the Hilo coast (Paper B). Cold land breezes extend to the upshore and lift the warm sea breeze air. Below $500 \mathrm{~m}$, a sharp temperature difference of about $1^{\circ} \mathrm{C}$ within a few hundred meters is measured at the boundary. An ascent rate of $1-2 \mathrm{~ms}^{-1}$ is observed at this boundary. When cold air from the land breeze is introduced into the moist sea breeze air at low levels, the cloud base height lowers by 100-200 meters. Raindrops are observed at the downwind side of the band cloud near the cloud top and rain falls in streaks beneath the cloud base. The width of the band where cumuli develop becomes greater as the relative wind speed at the mid-level of the trade wind layer becomes stronger. When the relative mid-level wind is $8 \mathrm{~ms}^{-1}$, band width is $15 \mathrm{~km}$ and several cloud cells are packed within the band along the wind direction. The drop water content near the cloud top increases somewhat more in band clouds than in isolated cumulus clouds.

\section{c. Cloud cluster}

When wind shear changes direction greatly at the inversion level or a strong wind blows 


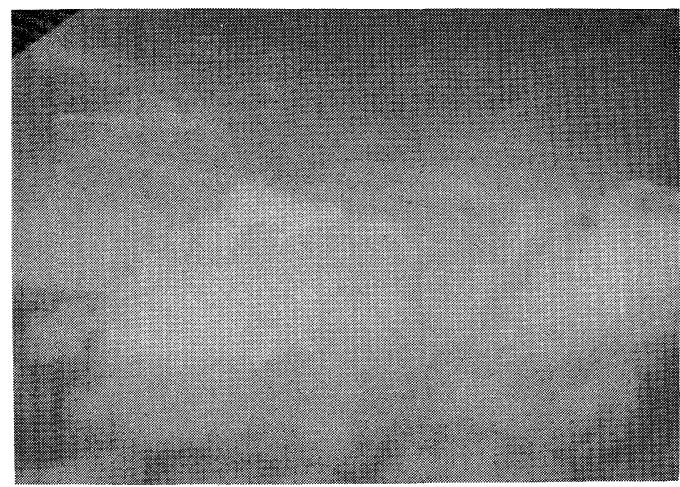

Fig. 1. Cloud cluster. Cloud top is about $2.5 \mathrm{~km}$.

above the inversion level, cloud clusters are observed (Fig. 1). Vertical velocity profiles show many updrafts near the cloud top. The size of the cloud clusters is roughly one order less than the clusters observed over the tropical open ocean (Houze and Betts, 1981). When band clouds have many updrafts near the cloud top across the band, they have also been included in the multi-cell cloud type for analysis of their drop growth processes. Cloud drop water contents near the cloud top are somewhat less than the values observed in the isolated cumulus clouds.

\section{Results}

4.1. The relation between wind profile and the growth rates of cloud droplets to drizzle and of drizzle to raindrops near the cloud top.

\section{a. Drizzle formation near the cloud top}

Near the cloud top, greater maximum drizzle $(200 \mu \mathrm{m} \leq \mathrm{D}<800 \mu \mathrm{m})$ water contents are observed when the maximum cloud drop $(\mathrm{D}<100$ $\mu \mathrm{m})$ water content is larger. However, drizzle formation is greatly dependent on wind shear (Fig. 2a).

In isolated cumulus clouds, drizzle formation is retarded when wind shear for speed at the cloud top is strong. In band clouds, drizzle formation is retarded when a strong wind blows at the cloud top or when a large variation in wind direction is observed there. However, in cloud clusters, more drizzle is formed near the cloud top when either the vertical variation in wind direction at the cloud top is large or when

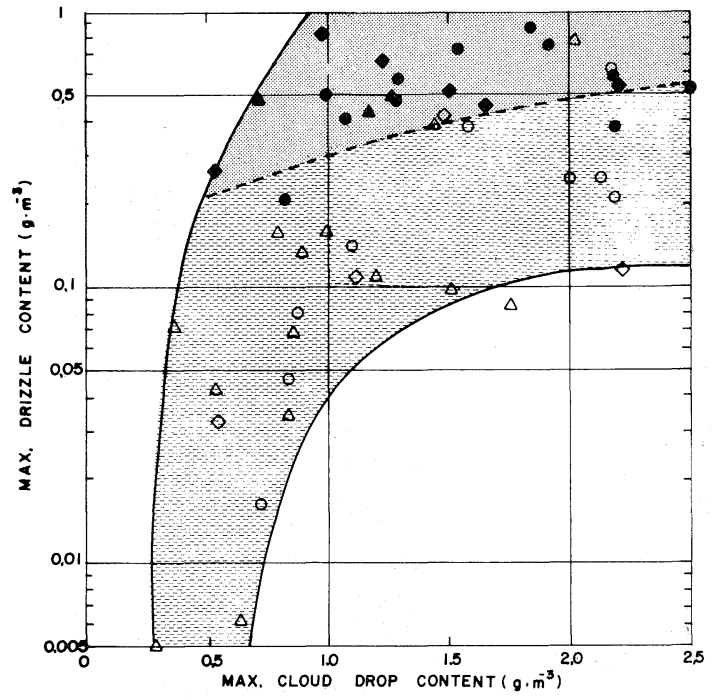

Fig. 2a. Maximum drizzle water content and maximum cloud drop content near cloud top. These are the maximum values gathered during the entire cell life. Triangles show isolated cumulus clouds, circles show band clouds and diamonds show cloud clusters. Solid triangles represent cases where changes of wind speed with height at the level of the cloud top is less than $2.5 \cdot 10^{-3} \mathrm{~s}^{-1}$. Open triangles show wind speed change is greater than the value. Solid circles are the cases where wind speed at the level of the cloud top is less than $7.5 \mathrm{~ms}^{-1}$ and change of wind shear angle with height at the level of the cloud top is less than $150^{\circ} \mathrm{km}^{-1}$. Open circles show where above conditions are not satisfied. Solid diamonds are the cases where change of wind shear angle with height at the level of the cloud top is greater than $100^{\circ} \mathrm{km}^{-1}$ or change of wind speed with height at the level of the cloud top is greater than $5 \cdot 10^{-3} \mathrm{~s}^{-1}$. Open diamonds show where above conditions are not satisfied. Dashed lines separate solid and open symbols and each region is shaded differently. Both wind shear and vertical variation in wind direction at the level of cloud top are calculated as follows: they are defined as the difference in magnitude between the cloud top and the place measured downward from the cloud top where the tendency in the variation of magnitude changes, divided by the difference in those distances.

the wind shear for speed there is great.

b. Raindrop formation near the cloud top

Near the cloud top, raindrops $(\mathrm{D} \geq 800 \mu \mathrm{m})$ are formed when the maximum drizzle water content is larger than about $0.03 \mathrm{gm}^{-3}$ and a greater amount of raindrop water is seen near the cloud top when a larger drizzle water content is observed there (Fig. 2b). However, in a case 


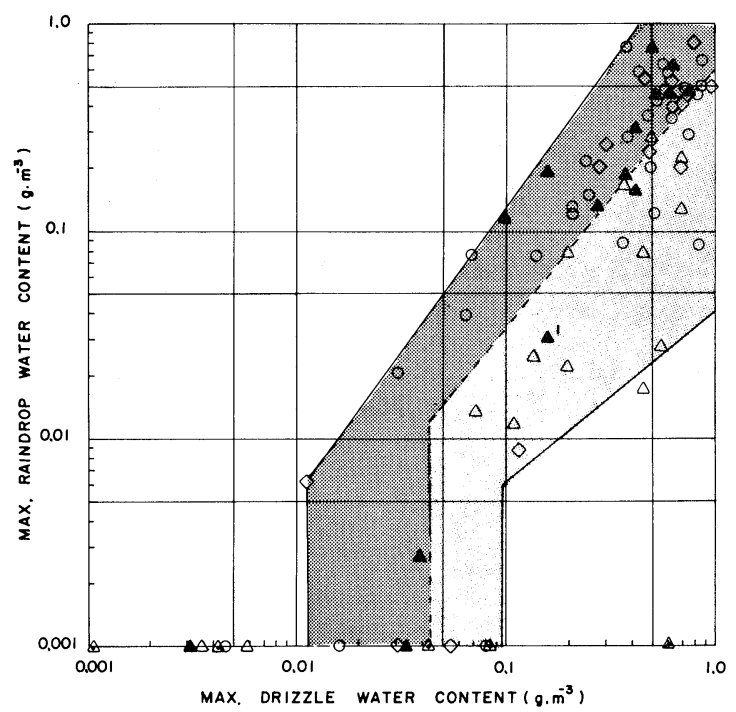

Fig. 2b. Maximum raindrop water content and maximum drizzle water content near cloud top. Triangles with center dot are the cases where temperature lapse rate between $0.5 \mathrm{~km}$ and $2 \mathrm{~km}$ is less than $5^{\circ} \mathrm{C} \mathrm{km}^{-1}$. Solid triangles are the cases where change in wind direction within the layer of cloud is less than $200^{\circ}$ and temperature lapse rate between 0.5 $\mathrm{km}$ and $2 \mathrm{~km}$ is greater than $5.7^{\circ} \mathrm{C} \mathrm{km}^{-1}$, respectively. Open triangles show where above conditions are not satisfied. Data falls approximately between two solid lines. Dashed line approximately separates open and solid triangles, which are differently shaded.

occurring on 12 April 1979 (right-bottom point in the figure), the temperature lapse rate was small $\left(\sim 5^{\circ} \mathrm{C} \mathrm{km}^{-1}\right)$ but the trade wind layer was very moist (93\%). The aircraft ascent rate near the cloud top was as weak as $1 \mathrm{~ms}^{-1}$. There was no raindrop formation although the maximum drizzle water content was high $\left(0.6 \mathrm{gm}^{-3}\right)$.

In isolated cumulus clouds, raindrop formation is slowed either when the wind direction change within the cloud is great or when the temperature lapse rate between $0.5 \mathrm{~km}$ and 2 $\mathrm{km}$ in height is relatively stable. There is one exception to these indications, labeled Case 1 in the figure. Here, there was a very strong wind shear for speed $\left(8 \cdot 10^{-3} \mathrm{~s}^{-1}\right)$ near the cloud top.

\subsection{The relation between wind profiles and the growth rates of drizzle and raindrops during their fall within cloud}

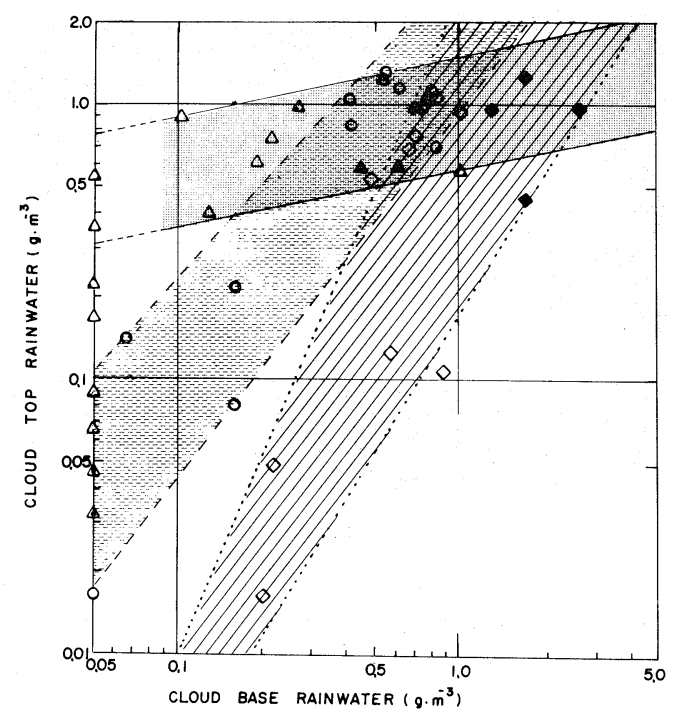

Fig. 2c. Maximum rainwater beneath cloud base versus maximum rainwater near cloud top. Triangles with center dot triangles are isolated cumulus clouds where cloud top height is less than $2.3 \mathrm{~km}$. Open triangles show where cloud top height is greater than $2.3 \mathrm{~km}$. Solid diamonds are the cloud clusters where change of wind speed with height at the level of cloud top height is greater than $5 \cdot 10^{-3} \mathrm{~s}^{-1}$. Open diamonds show where change of wind speed is less than the value. Isolated cumulus cloud, band cloud and cloud cluster regions are shaded with different patterns.

A greater rainwater (drizzle and raindrop) content is observed beneath the cloud base when the rainwater content is also greater near the cloud top (Fig. 2c). However, in isolated cumulus clouds a critical value of $0.3 \mathrm{gm}^{-3}$ of rainwater must be found near the cloud top in order to observe rainwater beneath the cloud base. No rainwater is seen when the cloud top height is less than $2.3 \mathrm{~km}$.

In band clouds, rain falls beneath the cloud base even when the maximum rainwater near the cloud top is lower than the critical value for isolated cumulus clouds. In cloud clusters, more rain is observed at the cloud base than in cases with isolated and band clouds, and a greater amount of rainwater is observed at the cloud base when the wind shear for speed at the cloud top is large.

\subsection{The relation between wind profile and rain duration}




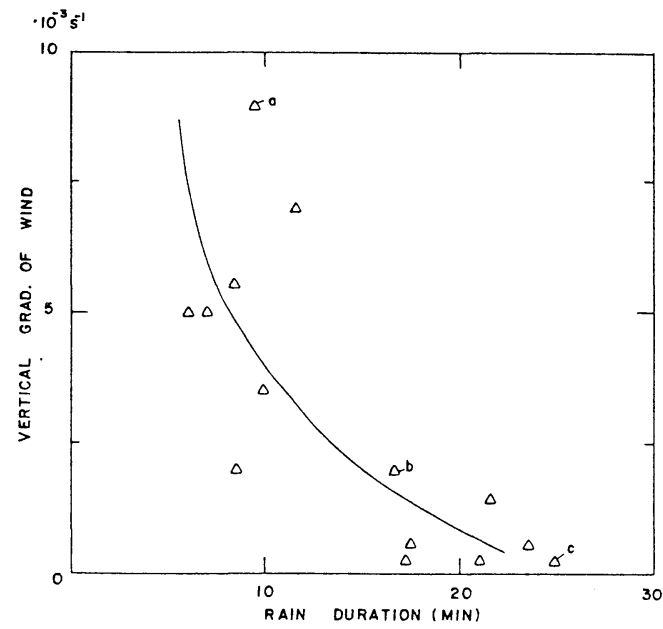

Fig. 3a. Duration of rain (higher than about $0.03 \mathrm{gm}^{-3}$ ) from isolated cumulus clouds as a function of the maximum vertical gradient of wind for speed within the layer of cloud. Solid line is drawn by eye to best fit the observational data. Cloud top height ranges from 2 to $3 \mathrm{~km}$.

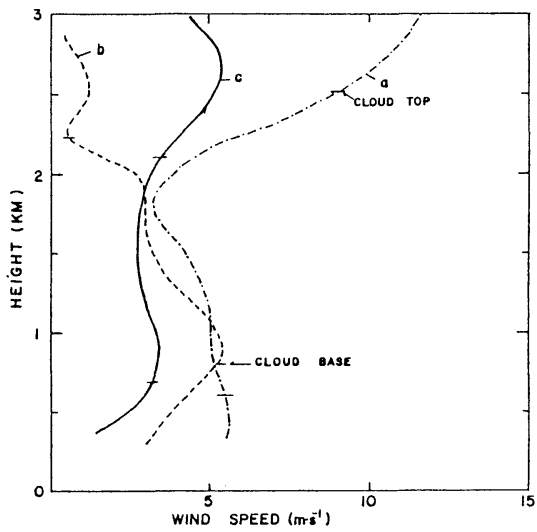

Fig. 3b. Vertical profiles of wind speed regardless of wind direction. Solid line (May 11, 1976), dashed line (June 1, 1976) and dash-dotted line (July 17, 1976).

\section{a. Isolated showers}

Rain from isolated cumulus clouds lasts for about 20 minutes when the wind shear within the cloud layer is weak. When there is a great change in wind speed in a vertical direction, the rain duration shortens (Figs. 3a, b).

Rain intensity increases sharply in the early stages of rain showers and then gradually weakens. Rainfall intensity at the cloud center is weaker than at the cloud boundaries in the early stages, and peak raindrops (the larger

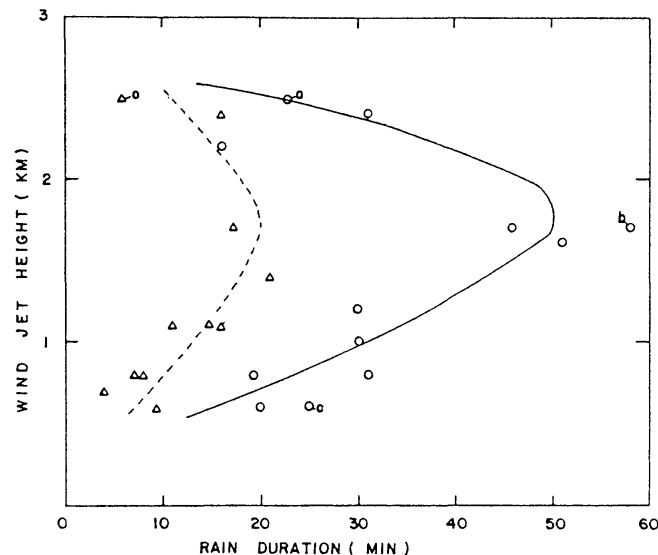

Fig. 4a. Rain duration is parabolic wind profiles as a function of maximum wind speed height with an prevailing wind component in the cases where the relative value of maximum wind speed is higher than $5 \mathrm{~ms}^{-1}$. Band clouds (circles) include both single and multi-updraft cases. Triangles are for isolated clouds developed outside of the sea breeze front. Both dashed and solid lines are drawn by eye to best fit observational data. Cloud top height ranges from 1.8 to $3.5 \mathrm{~km}$.

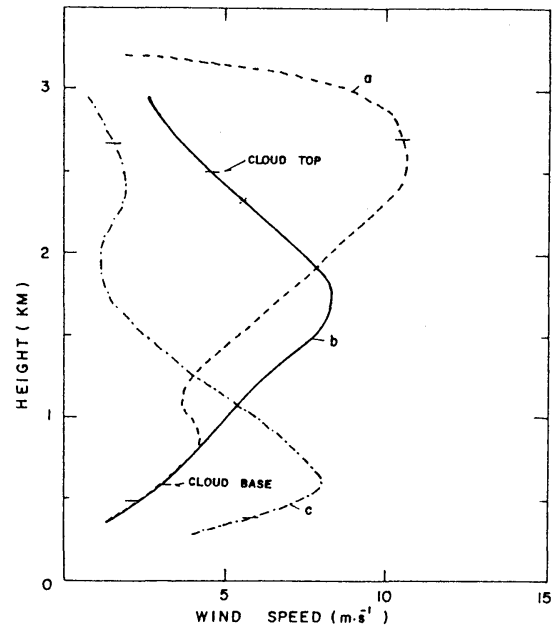

Fig. 4b. Vertical profiles of prevailing wind components. Solid line (May 28, 1976), dashed line (June $15,1976)$ and dash-dotted line (December 27, 1976).

modal size in the bimodal raindrop size distribution) are observed only when rainfall is intense (Fig. 12 in Paper A). There are no distinct peak raindrops seen when wind shear for speed is strong (Fig. 13 in Paper A).

b. Line showers

In a parabolic wind flow, rain from band 


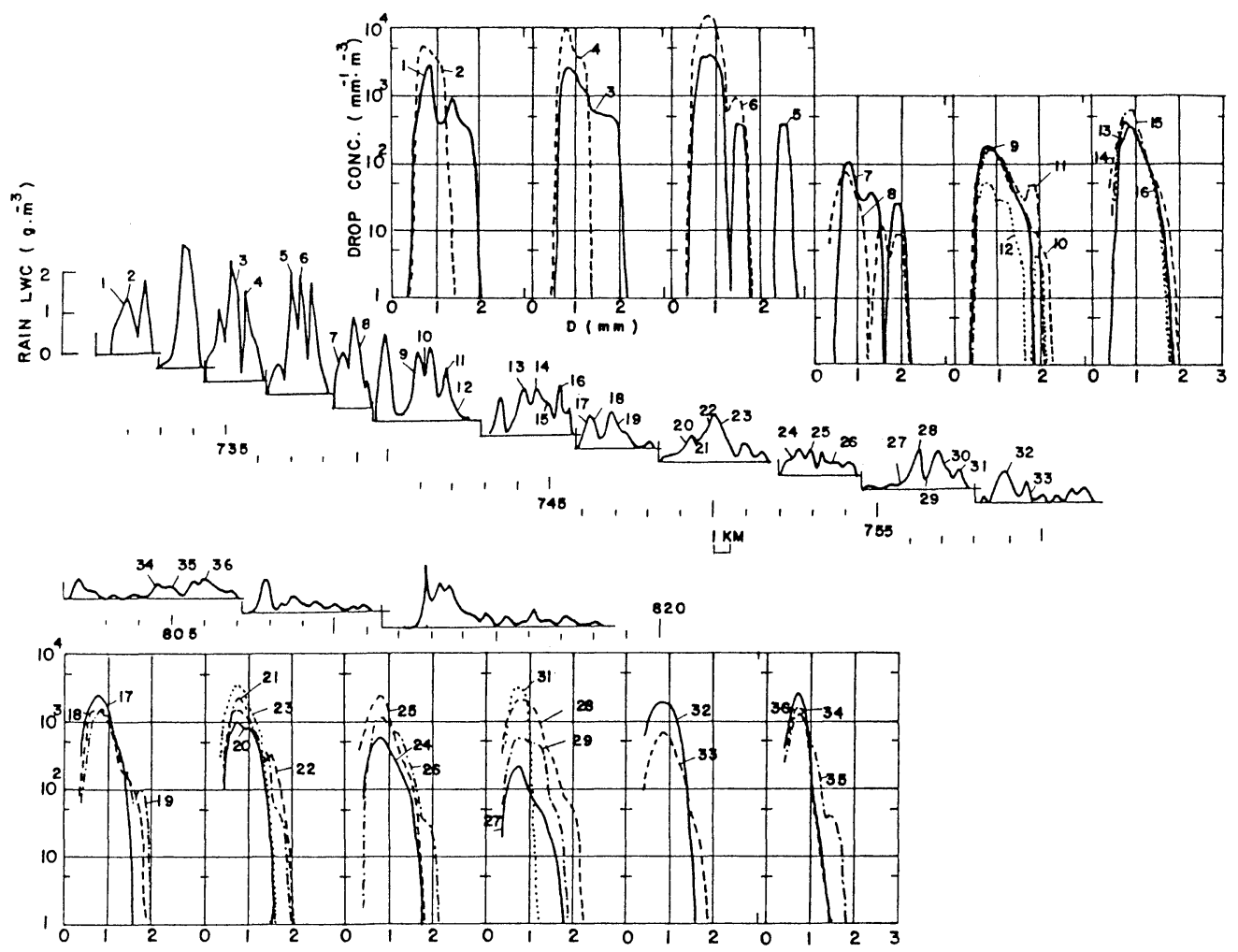

Fig. 5. Space and time rainwater profiles in band clouds across the shower at different times when a strong wind blows in the middle of the trade wind layer (26 August 1976). Rainwater content of $1 \mathrm{gm}^{-3} \mathrm{roughly}$ corresponds to $30 \mathrm{mmh}^{-1}$ in cloud model. Vertical axes in the boxes are the drop number concentrations and horizontal axes are the drop diameters. The sampling time is indicated in the rainwater profiles.

clouds lasts for a longer period of time, especially when a strong wind blows in the middle of the trade wind layer (Figs. $4 \mathrm{a}, \mathrm{b}$ ).

In situations like this, band cloud rain intensity increases sharply at the beginning of the shower and decreases gradually later (Fig. 5 and two other similar cases), as is also seen in cases when showers fall from isolated cumulus clouds with weak wind shear (Fig. 12 in Paper A). The rainfall area, however, broadens with time. Peak raindrops are observed during periods of intense rainfall, as in the cases when showers from isolated cumulus clouds occur with weak wind shear. When a strong wind blows at either the upper or lower levels of the trade wind layer, the rain shower lasts slightly longer than in situations where isolated cumulus clouds have a weak wind shear. Raindrop size distributions are sharp and peak raindrops are not yet distinct (13 cases, see Fig. 14 in Paper A). Rain duration from isolated clouds that develop outside of the sea breeze front becomes as short as $10 \mathrm{~min}$, except when a strong wind blows in the middle of the trade wind layer. In that case, rain duration is the same as from isolated cumulus clouds with a weak wind shear.

Although the maximum rainfall intensity from band clouds is higher than from isolated cumulus clouds (Paper A), there is no distinct relation between the maximum rainfall intensity and rain duration.

\subsection{The relation between the spatial distribu- tion of drops and the vertical velocity profiles near the cloud top}

a. Isolated cumulus clouds with weak wind shear When clouds are of moderate size (cloud top height, $2.7 \mathrm{~km}$ ), the ascent rate at the center of the cloud near its top increases to $4 \mathrm{~ms}^{-1}$ (Fig. 11a in Paper B and 7 other similar cases). At this time raindrops are formed at the cloud center. During rainfall, a relatively strong descent 

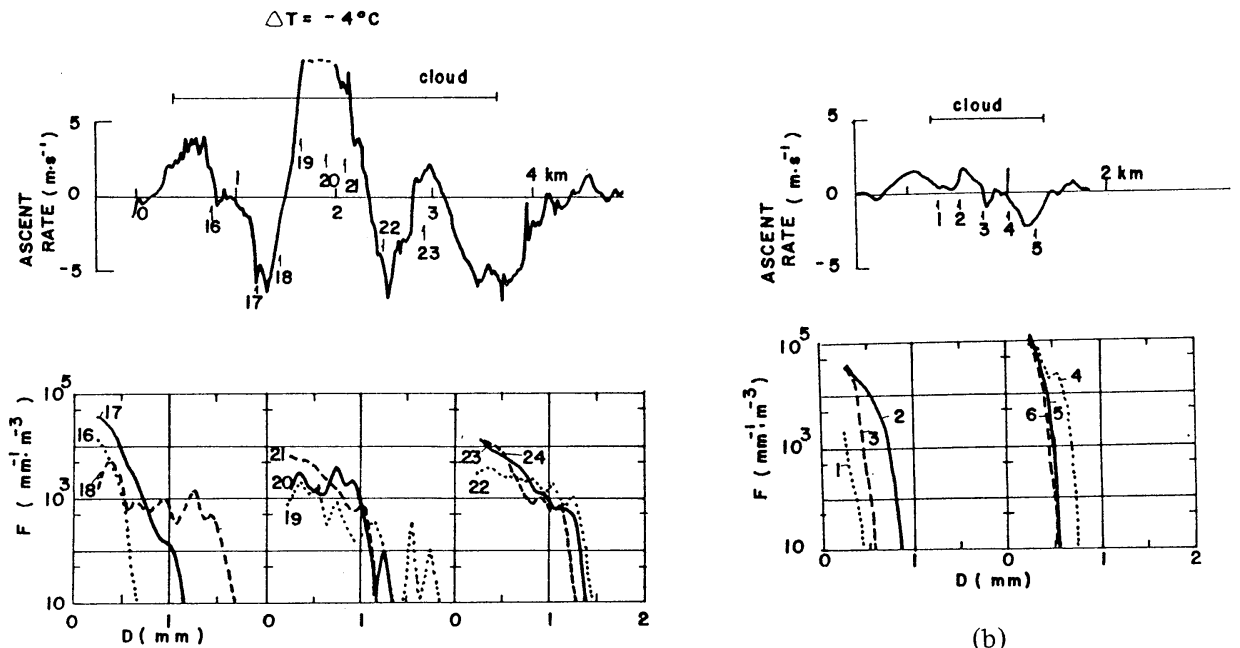

(a)

(b)

Fig. 6a. Aircraft ascent rate across cloud center near cloud top (13 June 1979) in an isolated cumulus cloud with weak wind shear. Drop sampling locations are indicated in the ascent rate profile and their drop distributions are shown in boxes. Cloud top and cloud base heights are $3.2 \mathrm{~km}$ and $0.6 \mathrm{~km}$, and the aircraft altitude is $3.0 \mathrm{~km}$.

Fig. 6b. Same as Fig. 6a except Apr. 12, 1979. Cloud top and cloud base heights are $2.4 \mathrm{~km}$ and 0.3 $\mathrm{km}$. Aircraft flies at $2.2 \mathrm{~km}$.

rate of $4 \mathrm{~ms}^{-1}$ is observed beneath the cloud base when the maximum rainwater content is $0.8 \mathrm{gm}^{-3}$ and the temperature is cooled $1^{\circ} \mathrm{C}$ by drop evaporation (15 May 1978). Peak raindrops are seen both near the cloud top and beneath the base.

When a taller cloud develops (cloud top height, $3.2 \mathrm{~km}$ ), the ascent rate at the center of the cloud near its top increases to greater than $8 \mathrm{~ms}^{-1}$ (Fig. 6a, two other similar cases). Because the cloud rises above the inversion level, the temperature in the cloud is $4^{\circ} \mathrm{C}$ cooler at this level than the outside air temperature. Relatively large raindrops are formed along the boundary between the updraft and downdraft.

When the trade wind layer is very moist $(>$ 93\%) but the temperature lapse rate is small $\left(\sim 5^{\circ} \mathrm{C} \cdot \mathrm{km}^{-1}\right)$, the ascent rate near the cloud top is as small as $1 \mathrm{~ms}^{-1}$ and only drizzle drops are formed (Fig. $6 \mathrm{~b}$ and one similar case). There is no peak raindrop formation and the cloud dissipates with drizzle fall.

b. Isolated cumulus clouds with wind shear

When wind shear for speed exists near the cloud top, an unsymmetric ascent rate profile is measured. Relatively large drops develop at

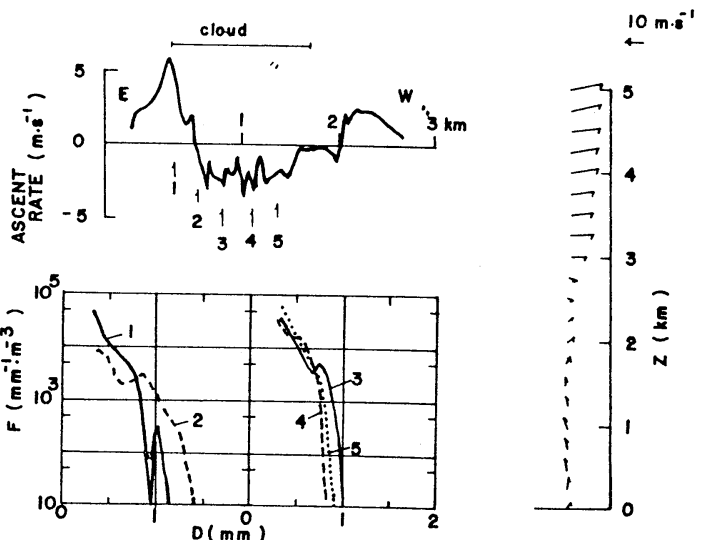

Fig. 7. Same as Fig. 6a except in an isolated cloud when wind shear is strong near the cloud top (26 March 1979). Cloud top and cloud base heights are $2.9 \mathrm{~km}$ and $0.4 \mathrm{~km}$. The flight is made at $170 \mathrm{~m}$ below the cloud top. The 0100 LST radiosonde wind data is plotted at the right.

the boundary between the updraft and downdraft (Fig. 7 and four similar cases).

c. Band clouds

When a parabolic wind profile exists, a downdraft forms on the upwind side of the cloud (east) while an updraft develops on the down- 


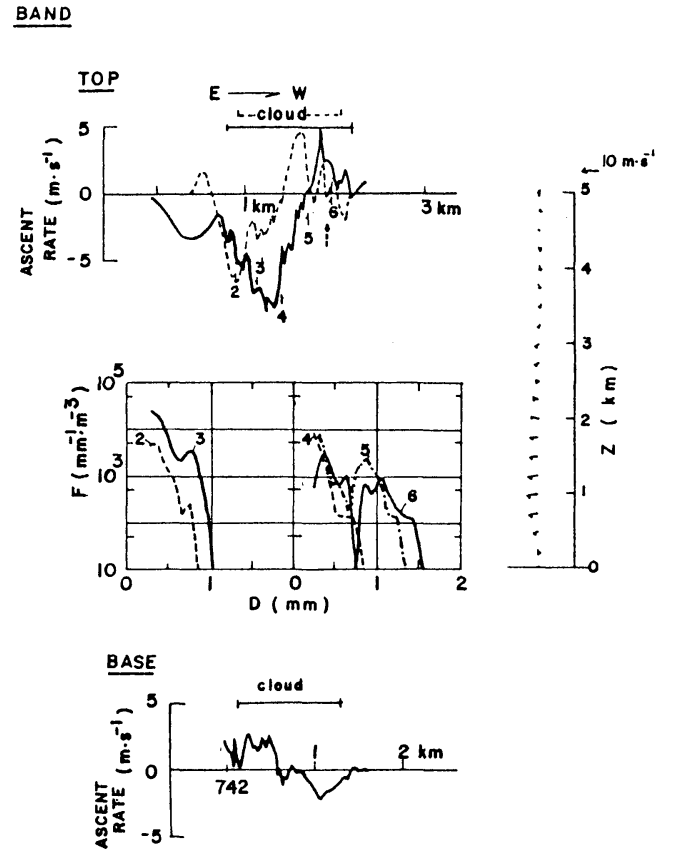

Fig. 8. Same as Fig. 6a except with a parabolic wind profile and in band clouds (April 5, 1979). The cloud top height is $3.3 \mathrm{~km}$ and the flight is made at $3.1 \mathrm{~km}$ from east to west. The ascent rate profile of another case (11 June 1979) is also shown in dashed lines. In this case, the flight is made from west to east and the largest raindrops are observed in the region shown by dashed arrows. The ascent rate beneath the cloud base (March 21, 1979) for a band cloud when a strong wind blows in the middle of a trade wind layer is also shown at bottom of figure. On March 21, 1979 the normal cloud base height is $500 \mathrm{~m}$ : it lowers to $200 \mathrm{~m}$ in the region of the band cloud. A flight is made at $300 \mathrm{~m}$. The incloud temperature at $300 \mathrm{~m}$ in the region of the lowered cloud base is $1.5^{\circ} \mathrm{C}$ lower than outside air temperature at same height.

wind side (west) near the cloud top. In contrast to isolated cumulus clouds, large drops are observed on the downwind side of the maximum updraft area. When strong winds blow in the middle of a trade wind layer, an updraft is seen on the east while a downdraft develops on the west beneath the cloud base (Fig. 8 and five similar cases).

\section{d. Cloud clusters}

When the wind direction changes greatly from southerly to northerly near the cloud top, large drops are observed in the southernmost cells (4 cases). When strong winds blow in the upper

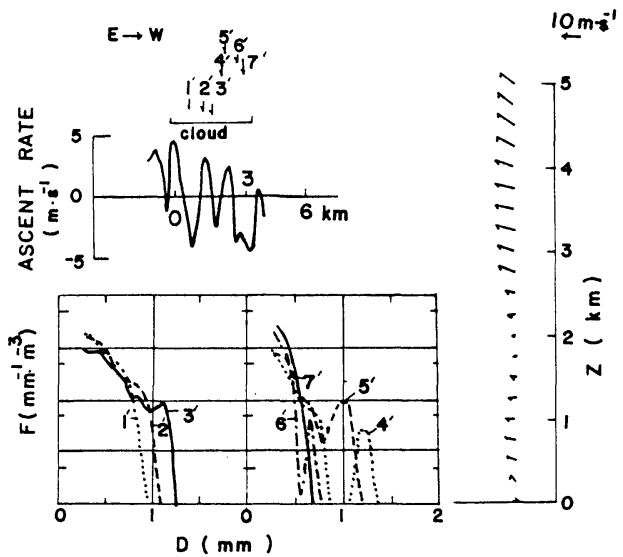

Fig. 9. Same as Fig. 6a except that in a cloud cluster when a strong wind blows at upper levels (June 12, 1978). Cloud top and base heights are $2.7 \mathrm{~km}$ and $0.6 \mathrm{~km}$. Flights are made at $2.5 \mathrm{~km}$.

levels above the cloud tops, large drops are observed at the top central boundaries between cells (Fig. 9 and three similar cases).

\section{Summary of observation}

a) The growth of drizzle near the cloud top is retarded with greater wind shear in both isolated and band clouds but accelerated in cloud clusters.

b) The growth of raindrops near the cloud top is retarded in isolated clouds either when the wind changes direction greatly in the cloud layer or the temperature lapse rate is relatively stable. There are no notable wind shear effects upon the raindrop growth rate in either band clouds or cloud clusters.

c) Accumulation of rainwater during precipitation particle fall within clouds is lowest in isolated clouds and highest in cloud clusters. Greater wind shear helps rainwater accumulation in cloud clusters.

d) Raindrops start forming near the cloud top when the updraft is more than moderate. A bimodal raindrop size distribution is seen near the cloud top and is observed during relatively intense rainfall beneath the cloud base.

e) In isolated cumulus clouds, rain duration shortens with wind shear. In band clouds, however, very long-lasting showers are noted when the wind shows a parabolic profile and 
a strong wind blows at the middle of the trade wind layer.

f) In band clouds, relatively large raindrops exist at the downwind side of the maximum updraft near the cloud top.

\section{Discussion}

a. Drop growth processes

Drizzle formation near the cloud top is retarded with wind shear in both isolated cumulus clouds and band clouds. According to model interpretations (Takahashi, 1981b, hereafter called Paper C) wind shear causes drops to be distributed widely in space so that drop growth by collection does not occur effectively. In the case of the cloud cluster, however, a higher drop growth rate is observed with greater wind shear. It is not clear if the role of wind shear is just to help form cloud clusters or whether in fact it plays a more positive role in accelerating drop growth.

As our cloud model predicted, raindrops are observed near the cloud top. Since raindrops have to float longer to grow larger, at least a moderate updraft is required near the cloud top. The observed poor raindrop formation in relatively stable environmental conditons and in strong wind shear conditions in isolated clouds is due to the weak updraft formation and fall of drizzle in weaker updraft areas. However, wind shear effects on raindrop growth in band clouds and cloud clusters involve more complicated dynamic structures that have not yet been studied in the model.

Bimodal raindrop distribution is observed near the cloud top. The model's interpretation is that since raindrops whose terminal velocities are greater than the maximum updraft can only fall, raindrops are sorted out in size.

Concerning change of rainwater during the fall of raindrops, the model (Takahashi, 1985) shows that downdraft formed along the cloud boundary carries down the mid-level low mixing ratio of water vapor to the cloud base. Since the cloud base height increases with time due to intrusion of dry air, evaporation of drops under the cloud base is a critical factor in observing rain at low levels in isolated cumulus clouds. Observation of the existence of the critical amount of rainwater near the cloud top needed to observe rainwater beneath the original cloud base level supports this concept. The reason that the observed rainwater content is greater beneath the cloud base level in band clouds and cloud clusters than in isolated cloud is considered to be that drops evaporate less in the long-time maintenance of a low level cloud base. This may be due to the low-level convergence in band clouds, and due to a wider cloud domain in cloud clusters.

In cloud clusters, large drops were observed at the centers of cells near the cloud top. It is not known at this time if this is due to the establishment of special dynamic profiles in the clouds or due to drop recirculation from one cell to another to enhance drop accumulation. More model work and observations are needed to clarify this situation.

\section{b. Rain duration}

Rain duration shortens with wind shear in isolated cumulus clouds. The model suggests that convection is greatly reduced since the downdraft is concentrated at the downshear of the cloud so that dry air is effectively included in the cloud (Paper C).

In band clouds, when the wind profile is parabolic and a strong wind blows at the middle of the trade wind layer, observation suggests the formation of a sloped updraft. Large raindrops fall to the downshear side of the updraft near the cloud top so that convection has a minimum interruption by drop drag force. Also the dynamically induced downdraft separates in location from that induced by drop drag force so that intrusion of dry air in the cloud base is minimum (Takahashi, 1985). When a strong wind blows either near the ground or at the cloud top, the characteristics of convection may be similar to isolated clouds with a linear wind shear.

The existence of low level convergence is also a factor in observation of long-lasting rainfall, because isolated clouds outside of the sea breeze front produce a rather shorter rain duration with similar wind profiles.

\section{Conclusion}

The wind shear effects on drop growth modes 
were studied through analysis of aircraft observations. An adequate updraft is required to develop raindrops near a warm cloud top. With wind shear, the drop growth rate is retarded by poor collection because drops are distributed widely in space and drizzle falls beyond the main updraft area. The rain which falls results in a reduced convection. However, when the wind has a parabolic profile and a strong speed at the middle of the trade wind layer, a sloped updraft is formed within the band cloud. In this situation, convection is not disturbed by the raindrop drag force and the inflow air is less modified by dry air. Low level convergence also helps to maintain the cloud. The rain lasts for a long time.

\section{Acknowledgments}

The author would like to express his sincere appreciation to Mr. J. Warner (NCAR), who kindly read this paper and helped to revise the manuscript with many useful suggestions. The author would also like to thank Dr. J. Dye (NCAR) who visited the Cloud Physics Observatory, examined airborne instruments and the aircraft data, and encouraged this analysis.
This project wsa supported by the National Science Foundation (ATM82-16598).

\section{References}

Houze, R.A., Jr. and A.K. Betts, 1981: Convection in GATE. Rev. Geophys. Space Phys., 19, 541-576.

Takahashi, T., 1976: Warm rain, giant nuclei and chemical balance - a numerical model. J. Atmos. Sci., 33, 269-286.

, 1977: A study of Hawaiian warm rain showers based on aircraft observations. J. Atmos. Sci., 34, 1773-1790.

, 1981a: Warm rain study in Hawaii-rain initiation. J. Atmos. Sci., 38, 347-369.

, 1981b: Warm rain development in a threedimensional cloud model. J. Atmos. Sci., 38, $1991-$ 2013.

- 1982: Electrification and precipitation mechanisms of maritime shallow warm clouds in the tropics. J. Meteor. Soc. Japan, 60, 508-519. - 1985: Warm rain process in Hawaii - wind shear effect in various cloud systems. Fourth WMO Scientific Conference on Weather Modification (Honolulu), 7-12.

Warner, J., 1969: The microstructure of cumulus cloud. Part 1. General features of the droplet spectrum. J. Atmos. Sci., 26, 1049-1059.

Woodcock, A.H., R.A. Duce and J.L. Moyers, 1971: Salt particles and raindrops in Hawaii. J. Atmos. Sci., 28, 1252-1257.

\section{温かい雨への風のシアーの影響}

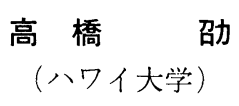

八ワイ洋上に発達する温かい雲の降水機構への風の鉛直シア一の影響を種々の䨌の夕イプについて飛 行機観測で得られたデーターの解析により調べた。雲頂附近での雲粒から霧雨 (drizzle)への成長は孤 立積雲及び帯状雲 (band cloud) では，風のシアーが遅らせる方向に働き，群雲（cloud cluster）では 加速する方向に働いている。そこでの雨滴の形成には適度の上昇気流が必要で, 雲内落下中での雨量の 増加は群雲で最大であった。降雨持続時間に関しては，孤立雲では，風のシア一が増すと短くなる傾问 があるが，帯状雲で風の高度分布が放物線で，強い風が貿易風の中央で吹くとき，降雨は非常に長く継 続した。 